\title{
Introduction: Sources of Strengths, Remaining Vulnerabilities and New Policy Challenges for Asia
}

\author{
Stephany Griffith-Jones and Ricardo Gottschalk
}

\begin{abstract}
1 Introduction
Currently, much of Asia, and especially East Asia, is growing at an impressive rate, though somewhat lower than before the East Asian crisis. According to World Bank (Ghosh 2006) estimates, the East Asian region has averaged 5.6 per cent a year annual growth during 2000-5. ${ }^{1}$ China is growing much faster. This is allowing for a very significant reduction in poverty. Continued high growth is crucial from a perspective of poverty reduction, as the number of poor people in East Asia is a high proportion of the world's poor. Furthermore, continued dynamism in Asia is an increasingly important pillar for growth in the rest of the world. Therefore, for both reasons, sustaining growth in Asia is important for meeting the Millennium Development Goals (MDGs), as well as for sustaining world economic growth.
\end{abstract}

One of the potential risks that could undermine continued rapid growth and poverty reduction in Asia is a financial crisis, especially if it spread through contagion from one country to another and/or if it occurred in a major country. The financial and development costs from the 1997/8 East Asian crisis were massive. Our estimates of forgone output in the four East Asian countries hit hardest by the crisis of 1997/8 - Indonesia, Korea, Malaysia and Thailand reach US\$917 billion, between 1997-2002, that is US $\$ 150$ billion annually (Griffith-Jones and Gottschalk 2006). If indirect effects of financial contagion in other countries and impacts via trade effects are added, the effect would be even larger. Eichengreen (2004) estimated that over the last quarter of a century, currency and banking crises have reduced incomes of developing countries by around 25 per cent. Therefore, it is very important to minimise the risk of crises occurring as much as possible.
Before outlining potential financial vulnerabilities and the challenges they pose to policymakers, we would like to emphasise another very important challenge for East Asian policymakers, which is to sustain high rates of growth. This could be made far more difficult if there was an abrupt adjustment of global imbalances (for a good discussion on their potential impacts on East Asia, see Eichengreen and Park 2006). Moreover, East and South-east Asian countries are increasingly dependent on exports as a source of growth. Adjustment of global imbalances leading to a global economic slowdown could hit these countries particularly hard. In addition, the low-income countries analysed in this IDS Bulletin have a narrow export base (though presently very dynamic), which make them even more vulnerable.

Moreover, the fact that investment rates - with the clear exception of China - remain significantly below pre-crisis levels (even though they tend to be well above levels for the rest of the developing world), may pose a challenge for future growth. Therefore, it is important that financial sectors in the region are not only stable and strong enough to minimise the risk of causing or magnifying any crisis, but that they also provide sufficient financing for both corporate investment and working capital for different categories of companies, including small and medium enterprises (SMEs).

Several articles in this IDS Bulletin highlight an important shift in the nature of the banking system. If in the past, the banking system was good for supporting growth but weak for risk management, since the crisis it has moved towards better risk management but also towards weaker support for corporate activity. Indeed, credit is shifting from 
producers to consumers and the mortgage sector, thus following a worldwide trend in bank lending. Of concern is whether these trends could undermine somewhat the high growth characteristic of East Asia.

\section{Sources of strength}

The current prospects for a new financial crisis appear to be low for much of East Asia. Many countries in the region have very strong macroeconomic fundamentals, although a few countries in the region, particularly Indonesia and the Philippines, do have quite significant fiscal deficits and large levels of public debt. It seems important that measures are taken for further improvement. It is also important that while governments exercise fiscal prudence, they also have the fiscal space to provide complementary investment to the private sector, e.g. in infrastructure - where needed.

Old potential sources of vulnerability, such as fragilities in the banking sector, seem to be increasingly overcome, as bank profitability increases, non-performing loans fall and capital adequacy ratios increase - in most East Asian countries these are now above the Basel minimum of 8 per cent. However, it should be emphasised that the standard financial ratios may overstate the performance and soundness of banks in some countries, due to differences in reporting standards and practices. Also, as the BIS 2005 Annual Report rightly points out improvements in East Asian banks' performance indicators partly reflects cyclical factors, which may be temporary. Furthermore, the non-performing loan ratio in East Asia on average remains high compared with other emerging market regions and profitability as well as risk-weighted capital adequacy ratios remain slightly lower. Moreover, although prudential regulation and financial indicators are improving, the important issue of currency mismatches are not being fully addressed, especially in the highly 'dollarised' countries.

An important policy challenge for East Asian bank regulators (explored below in this IDS Bulletin) is the introduction of the new Basel II regulatory framework. Policy issues arising, that the IDS Bulletin discusses, include the speed and modalities through which Basel II should be introduced, as well as the need to consider and try to counteract possible problematic aspects of the introduction of Basel II, such as potential increases in procyclicality of bank lending. Also, a key issue highlighted by the country articles is lack of capacity to implement Basel II, especially in the low-income countries where even Basel I is being hard to implement.

As regards reducing vulnerability to currency crises, most East Asian countries have built very strong defences in the form of extremely high foreign exchange reserves; for 2005, total foreign exchange reserves reached over US\$1.6 billion, which was not only a historical record, but also implied levels (both absolutely and as a percentage of GDP) far higher than for Latin American economies (Stallings 2006). Furthermore, except for Indonesia and the Philippines, for the major East Asian currencies, foreign exchange reserves are much larger than total external debt. As a result, foreign exchange reserves are - for those countries - much larger than short term debt, whose non-renewal is most likely to be problematic and can provoke currency crises (Rodrik and Velasco 1999). Indeed, for China, Prasad and Wei (2005) estimated that foreign exchange reserve holdings were ten times the level of short-term debt. The accumulation of such high levels of reserves - largely for self-insurance purposes, as well as a result of intervention to maintain competitive exchange-rates by East Asian authorities, provides a very valuable cushion against future external shocks, such as reversals of capital flows or others. The fact that most of the East Asian countries also have fairly low - and decreasing - debt ratios as well as large current account surpluses further reduces their external vulnerability. However, the build-up of large reserves has contributed to excessive liquidity, which has been a major factor behind bubbles in the stock markets of several Asian countries, and more broadly constituting an important challenge for such countries. Indeed, further research seems to be required to explore the policy trade-offs facing economic authorities in dealing with the issue of excessive liquidity.

\section{New policy challenges}

Even though there are many positive features and achievements in reducing financial vulnerability, there are also new challenges for East Asian policymakers. At one level, the uncertainties posed by the risk of an abrupt unravelling of global imbalances, or of sharply rising oil prices, may drastically change the prospect for developing economies. More broadly, increased dependence of developing countries on export-led strategies may have created more 
vulnerability to trade cycles; the interaction between large trade and capital account changes could pose new sources of vulnerability.

Challenges that the low-income countries covered in this IDS Bulletin face in particular are their high degree of 'dollarisation', the currency mismatches that it implies, and how de-dollarisation may be engineered successfully. This is another area that certainly deserves further research.

At another level, new sources of potential vulnerability have arisen within the global and national financial sectors. The explosive growth of derivatives worldwide, and increasingly in developing economies, have certain advantages, such as the fact that they help, at a microeconomic level, corporates and other actors to transfer risks to those who seem better able and willing to bear them. However, they can also pose new risks for the stability of the whole financial system and may have destabilising and procyclical effects on key macroeconomic variables, such as capital flows and the exchange rate, which can have harmful effects on economic growth.

Furthermore, the article on China in this IDS Bulletin argues for prudence in liberalising the capital account. It moreover makes the point that, as a result of the lessons learned from the 1997 crisis, China has adopted a careful approach towards capital account liberalisation, and that this approach has led to the positive fruits of a safe model with sustainable growth.

To summarise, East Asian economies seem to be in a strong position to withstand crises. Many of the weaknesses that contributed to, or resulted from, the East Asian crisis, seem to have been overcome in a rather impressive way. These relate in particular to vulnerabilities to short-term capital outflows and to weaknesses in the banking systems. However, new policy challenges arise, such as how to respond to a possible slowdown in the world economy.

\section{Building on our past work and drawing on the} Bangkok conference

In 1998, the Institute of Development Studies (IDS) hosted a major international conference on the East Asian crisis, which resulted in an IDS Bulletin, and was followed by a book on the crisis (see Griffith-Jones et al. 2003). In 2006-7 the UK Department for International Development (DFID) funded the IDSled project on 'Vulnerabilities to Crises and MDGs'.
As part of this project, in February 2007 a major conference on 'The Ten Years after the Asian Financial Crisis: Vulnerabilities of East Asia' was held in Bangkok. The conference was co-organised by IDS, the Thai Development Research Institute (TDRI) and the Seoul National University; institutions that also provided funding. It benefited from the participation of senior academics from the region and elsewhere, senior officials from international organisations and Asian governments.

This IDS Bulletin builds on past research, both on Asia and on the international financial architecture. It is based on the Bangkok conference, bringing together the papers that were presented on that occasion. Although the global and regional dimensions of the issues and challenges facing Asia nowadays are also very important ones, the IDS Bulletin articles - as well as this research project - have mainly a national focus.

The article by Park and Wyplosz offers an overview of recent developments among East Asia's emerging market economies (EMs), including China. It shows that most East Asian countries have made considerable progress in making their financial systems more resilient, having prudent macroeconomic policies, and having accumulated large amounts of foreign exchange reserves. But it argues that although risks have been reduced, they have not been totally eliminated. Among the potential sources of vulnerability common to nearly all countries analysed are their high dependence on exports as a driver for growth, which makes them vulnerable to trade shocks; and asset inflation, for example via real estate market bubble - in the latter case already in the making in China and Korea. Also, progress has been somewhat uneven across countries, with Indonesia and the Philippines lagging behind other countries in reducing financial vulnerability.

The article by Yongding on China, while emphasising the extremely positive economic growth performance China has had so far, also identifies key threats to the country's economic stability in the future. Among the sources of vulnerability are: a still somewhat fragile financial system, in particular banks, despite recent reforms in the system and improvements in some of its key indicators; the excessive liquidity in the economy, which is a major factor behind bubbles and inflation. The article also discusses how China may prevent a crisis from happening, highlighting the role capital controls can 
play in crisis prevention, and draws lessons on this from the Asian crisis.

The article by Siamwalla on Thailand, where the 1997 crisis began, starts by affirming that, although Thailand faced a major currency crisis, it was the massive failure of the financial system that had a more profound impact; in light of this initial assessment, it focuses on the changes that occurred in the Thai financial system since 1997. It argues that, although progress in reforming the financial system has been made, putting it on a much stronger footing today, reforms are still incomplete, and thus in need of further work. With regard to the ability of this new financial system to support the economy, the article points to the fact that the Thai private banking sector is now extremely wary about lending to large business, turning to consumer lending and mortgages. As banks have retreated in their historical role of supplying capital to large companies, the capital markets have stepped in and thus become an important source of funding to such companies.

As pointed out earlier, this pattern in bank lending a shift away of lending from productive activities and towards consumer and mortgage - has been identified in several country studies.

Adiningsih in her article on Indonesia discusses the country's recovery from the crisis and the reforms that were undertaken to support the recovery process; also, as in the other country articles, she identifies remaining and new sources of vulnerability. She argues that thanks to sound macroeconomic policies and reforms in the financial sector and the economy more broadly, recovery eventually came to fruition, even though it took longer than in other crisis-affected countries in the region. But the article argues that it is not always the case that major reforms necessarily guarantee continued macroeconomic stability and sustainable economic growth. It shows that the Indonesian economy remains very vulnerable, and that there is not a better symptom of this than the mini crisis that hit the country in 2005, just a year after recovery from the 1997 crisis had been fully achieved. The article points out that, in addition to the remaining weaknesses Indonesia still faces - fiscal deficit, government debt and relatively low foreign reserves as a proportion of key variables such as short-term debt, two drawbacks characterise the economy nowadays: the slow growth performance of the productive sectors relative to the financial sector, and the increased dependence on short-term capital flows.

The article on Malaysia by Kadir shows that the recovery in the Malaysia economy since 1998 has been due mainly to exports, private consumption, and a boost in public investment, even though there is a lower investment level, than in the past. It argues that Malaysia is unlikely to return to the rapid growth of the pre-crisis period due to the changing and more challenging global economic environment. Like many other Asian countries, Malaysia has accumulated high levels of foreign reserves, thereby protecting the country from speculative behaviour by international investors. But an important source of vulnerability remains on the trade side, as Malaysia's exports are still fairly concentrated on electronic goods.

Debuque-Gonzales and Gochoco-Bautista writing on the Philippines make the point that unlike the other crisis-afflicted countries where financial fragility is a main concern, the Philippines' largest worry is instead how to effectively leverage for long-term growth. As they emphasise, economic growth in the post-crisis period, although respectable, has not been fast or strong enough for the country to catch-up with the rest of East Asia. In regard to sources of vulnerabilities, like in Indonesia, the authors highlight the fact that foreign reserves have not been as large as in other countries in the region, and that fiscal deficit and debt levels remain higher than in neighbouring countries as a proportion to national income.

It is also very important to see how the low-income countries in Asia are performing. And, as these countries become new emerging economies, what vulnerabilities may start to build up and what lessons can be learned so that these countries do not face a major financial crisis in the future, which could derail growth and have devastating poverty impacts. To fill this gap, this IDS Bulletin brings an article on three low-income countries from the Mekong region: Cambodia, Laos and Vietnam (CLV).

In addressing possible exposure to financial vulnerabilities in these three countries, Thanh, Chea, Ouk and Sang shed light on possible risks associated with developments in key macroeconomic fundamentals, the financial system and foreign exchange policies that followed the market-oriented reforms that the CLV countries have undertaken since the late 1980s. The authors show that the market 
reforms have led to major changes in the CLV economies and contributed to fast economic growth and development in the 1990s and early 2000s. However, informed by the events related to the Asian crisis, they argue that the liberalisation process, if implemented improperly, could involve risks. Key issues facing the CLV countries nowadays and for the future include the facts that: to different degrees, these countries still rely significantly on external resources to finance their investment-saving gap, which are especially large in the cases of Cambodia and Laos, given their fairly low savings rates; external trade has become a major driver of growth, but the downside is that given their limited range of export products and with low value-added, they are vulnerable to international trade shocks and disputes, and global recession. Domestically, these countries have been financially supported by weak banking systems that need further strengthening, despite progress made in recent years. $A$ major issue is the fact that they face high levels of dollarisation, especially Cambodia and Laos, which - as is known from international experiences - can imply greater vulnerability to shocks.

The CLV article suggests a number of common and country-specific policies for sustaining growth and development, including: further market-oriented reforms and strengthening macroeconomic fundamentals; improvements in the business environment to attract both domestic private investment and FDl; strengthening banking regulation and supervision; promoting financial intermediation, especially lending (which is particularly relevant for Cambodia where intermediation levels are very low); having a proper

\section{Note}

1 This data includes China, Hong Kong (China), Indonesia, Korea, Malaysia, The Philippines, Thailand and Singapore; if other East Asian countries were added, the outcome would be similar.

\section{Bibliography}

Eichengreen, B. (2004) Global Imbalances and the Lessons of Bretton Woods, NBER Working Working Paper 10497, Cambridge: National Bureau of Economic Research

Eichengreen, Barry and Park, Yung Chul (2006) 'Global Imbalances: Implications for Emerging roadmap or sequencing for financial integration and liberalisation to ensure a safe, proper process of multi-stage liberalisation; and in the cases of Cambodia and Laos, reducing significantly their degree of dollarisation.

The final article, by Griffith-Jones and Gottschalk, offers policy suggestions for greater financial stability. It discusses only very briefly the need for further reforms in the international and regional financial architecture, as it has been done exhaustively elsewhere (see, e.g. Griffith-Jones and Ocampo 2003 and 2007 for the former, and Park et al. 2006 for the latter). It focuses instead on initiatives that can be pursued by national governments to deal with new sources of potential vulnerability that have arisen within the global and national financial sectors, such as derivatives. While these new financial instruments help corporates and other actors to transfer risks to others better able and willing to bear them, they can also pose new risks for financial stability and have destabilising and procyclical effects on key macroeconomic variables, such as capital flows and the exchange rate. To help reduce such vulnerabilities, the article proposes the design and issuance of new instruments, such as GDP-linked bonds, that can better diversify risks that countries face due to their increasing integration in the world economy. The article also discusses the adoption of Basel II and its possible unintended effects such as increased procyclicality. It therefore recommends measures to try to compensate increased procyclicality, as well as a gradual approach to its adoption, especially in low-income countries, where capacity implementation is a major constraint.
Asia', presented at one IADB Annual Meeetings Seminar, Madrid, 15-16 May

Eichengreen, Barry; McCauley, Robert and Park, Yung Chul (2006) Asia Bond Markets: Issues and Prospects, BIS Papers 30, Basel: Bank for International Settlements (BIS) 
Ghosh, S.R. (2006) East Asian Finance: The Road to Robust Markets, Washington DC: The World Bank, The International Bank for Reconstruction and Development

Griffith-Jones, S. and Gottschalk, R. (2006) 'Financial Vulnerability in Asia', in M. Robinson and J. Farrington (eds), 'Asia 2015: Sustaining Growth and Ending Poverty', IDS Bulletin 37.3: May

Griffith-Jones, S. and Ocampo, J.A. (2007) A Counter-cyclical Framework for a Developmentfriendly International Financial Architecture, forthcoming

Griffith-Jones, S., Gottschalk, R. and Cailloux, J. (eds) (2003) International Capital Flows in Calm and Turbulent Times: The Need for New International
Architecture, Ann Arbor: The University of Michigan Press

Griffith-Jones, S. and Ocampo, J.A. (2003) What Progress on International Financial Reform? Why so Limited?, available www.egdi.gov.se/publications.htm (accessed 18 May 2007)

Prasad, E. and Wei, S. (2005) The Chinese Approach to Capital Inflows: Patterns and Possible Explanations, IMF Working Paper April, Washington DC: IMF Rodrik, D. and Velasco, A. (1999) Short-term Capital Flows, NBER Working Paper W7364, Cambridge, MA: National Bureau of Economic Research

Stallings, B. (2006) Finance for Development: Latin America in Comparative Perspective,

Washington DC: Brookings Institution Press 